\title{
A Rare Cause of the Rare Condition: Paratesticular Fibrous Pseudotumor
}

\section{Nadir Bir Durumun Nadir Bir Nedeni: Paratestiküler Fibröz Psödotümör}

\author{
Mehmet Reşit Gören1, Cevahir Özer1, Nebil Bal2 \\ ${ }^{1}$ Başkent University Adana Medical and Research Center, Clinic of Urology, Adana, Turkey \\ 2Bașkent University Adana Medical and Research Center, Clinic of Pathology, Adana, Turkey
}

\begin{abstract}
Benign fibrous proliferations of the spermatic cord are uncommon and mostly arise from the paratesticular region. Although benign, they often clinically mimic malignancy and usually remain undiagnosed preoperatively. Here, we report a case of fibrous pseudotumor arising from the right spermatic cord encountered in a 26 -year-old male who presented with a palpable right inguinal mass.
\end{abstract}

Keywords

Paratesticular tumor, fibrous, pseudotumor

\section{ÖZ}

Spermatik kordun benign fibröz proliferasyonları nadirdir ve çoğunlukla paratestiküler bölgeden kaynaklanmaktadır. Benign olmalarına karşın, klinik olarak sıklıkla maligniteyi taklit ederler ve genellikle preoperatif olarak tanı konulamaz. Bu olgu sunumunda, spermatik kord kaynaklı fibröz psödotümöre bağlı sağ inguinal kitle ile başvuran 26 yaşında bir erkek hastayı sunuyoruz.

Anahtar Kelimeler

Paratestiküler tümör, fibröz, psödotümör

\section{Introduction}

Paratesticular fibrous pseudotumors (PFPT) are rarely encountered and fibrous pseudotumors have been reported to comprise approximately $6 \%$ of all paratesticular lesions and tumors (1). It is also known as chronic periorchitis, proliferative funiculitis, fibrous proliferation of the tunics, fibroma, nonspecific paratesticular fibrosis, nodular fibrous periorchitis, nodular fibrous pseudotumor, inflammatory pseudotumor, reactive periorchitis, and pseudofibromatous periorchitis (1). The aetiology of PFPT is still unclear, but hydrocele, epididymo-orchitis, hematocele and trauma are considered as predisposing factors (1). PFPT does not show an age predilection and is usually characterized by multiple, sometimes solitary paratesticular nodules and minority of the cases are adherent to the spermatic cord or epididymis (2). The tumor is characterized by the presence of dense hyalinized collagenous tissue with interspersed spindle cells as well as a lymphoplasmacytic infiltrate. We describe the case of a young male presenting with a painless inguinal nodule.

\section{Case Presentation}

A 26-year-old male with an excellent health condition presented to the clinic with a painless right subinguinal mass. He realized a palpable mass during self-examination that he was doing since 2 years. There was no history of scrotal trauma and infections. The nodule was hard, mobile and easy to palpate. Ultrasonography (US) of the inguinal region and scrotum revealed a hypoechoic, hypovascularized, 15×15 $\mathrm{mm}$ mass within the right spermatic cord. Laboratory examinations, including testicular tumor markers were within the normal limits. During the inguinal exploration, the mass was strictly attached to the right spermatic cord 3-4 cm above the external inguinal ring. Excision of the mass was easy and the frozen section yielded no malignancy, thus, radical orchiectomy was avoided.

On microscopic examination, the specimen was composed of dense, collagen-rich, hyalinized, partly storiform fibrotic tissue and a low cell density of interspersed spindle-like cells, inflammation, lymphocytes, mast cells and neutrophils. The specimen had positive staining for calponin and negative staining for smooth muscle actin (SMA), h-Caldesmon, CD-34 and S-100 yielding a fibrous pseudotumor (Figure 1).

\section{Discussion}

PFPT's are exceptionally rare tumors. In their study, Miyamoto et al. (3) (2010) reported a mean age of 42 years at presentation, however, in the

\section{Correspondence}

Mehmet Reşit Gören MD, Başkent University Adana Medical and Research Center, Clinic of Urology, Adana, Turkey

E-mail: drresitg@yahoo.com Received: 27.02.2015 Accepted: 05.03.2015 




Figure 1. a) Dense, collagen rich, hyalinized, stroma with interspersed spindle-like cells and inflamatory cells (HaemotoxylinctEosin (HE) x40), b) Dense, collagen rich, hyalinized, stroma with interspersed spindle-like cells and inflamatory cells (HEx200), c) Calponin positive staining cells (Calponin x200)

literature, there are reported cases of PFPT in children and adolescents (4). Considering previous reports, PFPTs are expected to arise on the left side and more commonly observed on the tunica vaginalis, epididymis, or the tunica albuginea $(4,5)$. Our patient was considerably younger and the PFPT was within the right spermatic cord, which makes our case to be rather unusual. The patient has noticed the lesion during self-examination, therefore, suspicion of malignancy was the reason for admission to the hospital; preoperative work-up could not exclude malignancy. The typical ultrasonographic features of PFPT include sharp margins of the lesion, localization of the lesion outside of the testicular parenchyma, and usually, homogeneously hypoechoic echo pattern (6). But in spermatic cord lesions, such as in our case, US cannot distinguish malign from benign lesions (7). Magnetic resonance imaging (MRI) of PFPTs has been reported only in a few cases (5). Fibrous pseudotumors demonstrate uniformly low signal intensity on T1- and T2-weighted images because of the presence of fibrosis, therefore, malignancy cannot be ruled out (8). Due to limitations of MRI in investigating these lesions and ultrasonographic characteristics of the lesion, we preferred inguinal exploration and frozen section examination to identify the nature of the lesion.

PFPTs may belong to lgG4-related diseases, such as retroperitoneal fibrosis, sclerosing pancreatitis and cholangitis, Riedel thyroiditis and sclerosing sialadenitis (2). However, our case had no signs of these diseases.

Paratesticular malignant tumors occurring in adults include rhabdomyosarcoma, leiomyosarcoma, liposarcoma, fibrosarcoma, malignant fibrous histiocytoma, and metastatic carcinomas. PFPT may present as diffuse or nodular masses, which might be considered as malignant clinically. The differential diagnosis of fibrous pseudotumor of the testicular tunics includes idiopathic fibromatosis, solitary fibrous tumor, fibroma of the tunics, leiomyoma, and neurofibroma (9). Surgical management is the treatment of choice for all of these lesions. The morphologic appearance of the lesion, presence or absence of an infiltrative border and the findings of immunohistochemical studies are useful in distinguishing these entities. In our case, immunohistochemical studies revealed positive staining with calponin, which identifies the myofibroblastic differentiation. The specimen had negative staining with SMA, h-Caldesmon, CD-34 and S-100 which indicate leiomyoma, solitary fibrous tumor and neurofibroma, respectively.

PFPT is rare but the third most common extratesticular mass after lipoma and adenomatoid tumor. Awareness of this entity combined with frozen section would help both the surgeons and pathologists to prevent an unnecessary orchiectomy, especially in younger patients. In addition, self-examination is essential for early detection of testicular or paratesticular lesions such as PFPT, therefore, we would like to emphasize the importance of self-examination of scrotal region especially for young adult men (10).

\section{Authorship Contributions}

Informed Consent: Consent form was filled out by all participants. Concept: Mehmet Reşit Gören, Design: Mehmet Reşit Gören, Nebil Bal, Data Collection or Processing: Mehmet Reşit Gören, Cevahir Özer, Analysis or Interpretation: Mehmet Reşit Gören, Nebil Bal, Literature Search: Mehmet Reşit Gören, Cevahir Özer, Writing: Mehmet Reşit Gören, Nebil Bal, Peer-review: Internal peer-reviewed, Conflict of Interest: No conflict of interest was declared by the authors. Financial Disclosure: The authors declared that this study has received no financial support.

\section{References}

1. Tobias-machado $M_{1}$ Correa Lopes Neto A, Heloisa Simardi L, Borrelli M, Wroclawski ER. Fibrous pseudotumor of tunica vaginalis and epididymis. Urology 2000;56:670-672.

2. Bösmüller $H$, von Weyhern $C H$, Adam $P$, Alibegovic $V$, Mikuz G, Fend $F$. Paratesticular fibrous pseudotumor-an IgG4-related disorder? Virchows Arch 2011;458:109-113.

3. Miyamoto $H$, Montgomery EA, Epstein Jl. Paratesticular fibrous pseudotumor: a morphologic and immunohistochemical study of 13 cases. Am J Surg Pathol 2010;34:569-574.

4. Vates TS, Ruemmler-Fisch C, Smilow PC, Fleisher MH. Benign fibrous testicular pseudotumors in children. J Urol 1993;150:1886-1888.

5. Dieckmann KP, Struss WJ, Frey U, Nahler-Wildenhain M. Paratesticular fibrous pseudotumor in young males presenting with histological features of IgG4-related disease: two case reports. J Med Case Rep 2013;7:225.

6. Germaine P, Simerman LP. Fibrous pseudotumor of the scrotum. J Ultrasound Med 2007:26:133-138.

7. Kyratzi I, Lolis E, Antypa E, Lianou MA, Exarhos D. Imaging features of a huge spermatic cord leiomyosarcoma: Review of the literature. World J Radiol 2011;3:114-119.

8. Cassidy FH, Ishioka KM, McMahon CJ, Chu P, Sakamoto P, Lee KS, Aqanovic L. MR imaging of scrotal tumors and pseudotumors. Radiographics 2010;30:665-683.

9. Bharti JN, Dey B, Mittal A, Arora P. A case of fibrous pseudotumor of the paratesticular region. World J Mens Health 2013;31:262-264.

10. Kuzgunbay B, Yaycioglu O, Soyupak B, Kayis AA, Ayan S, Yavascaoglu I, Cal C Beduk Y; Turkish Study Group of Public Awareness in Testicular Cancer. Public awareness of testicular cancer and self-examination in Turkey: a multicenter study of Turkish Urooncology Society. Urol Oncol 2013;31:386-391. 